\title{
UV Visual Spectral Response of Transformer Oil Under The Impact of Thermal and Electrical Stress
}

\author{
Murugesan Srinivasan $^{1}$, Sumarkumar Burnwal ${ }^{2}$ \\ Department of EEE, Navodaya Institute of Technology, Raichur, Karnataka ${ }^{1}$, \\ Department of Physics, Navodaya Institute of Technology, Karnataka ${ }^{2}$ \\ (srinimeha@gmail.com)
}

\begin{abstract}
The complete lifetime of power transformers relies on the state of the oil insulation frame work all through perpetual action. Power transformers are one of the significant bits of intensity hardware in power systems. To determine the operating behavior of transformer, it is necessary to possess investigations on ageing of transformer oil paper insulation owing to thermal degradation under electrical stress. During this analysis the parameters like Breakdown Voltage (BDV), acidity, viscosity, dielectric constant and spectral response were observed for the study. An absolute Thermal-Electrical StressUltraviolet (UV) visual analysis test has been administered to research the spectral response of transformer oil. A comparative analysis has additionally been created for the spectral response and thermal degradation parameters of transformer oil under the impact of electrical stress. It is concluded that the proposed method is useful to evaluate the unconsumed life of oil insulation, which can build up the maintenance and repair policies of transformer owner.
\end{abstract}

Keywords:Thermal-Electrical Stress, Thermal degradation, Transformer oil, Ultraviolet (UV) visual spectral respose

\section{Introduction}

The study of reliableness of power transformers needs the elaborated and correct models that review the responsible characteristics specifically whole internal voltage distribution and input-output responses. For oil-immersed liquid-cooled transformers, the responsible parameters for the aging of insulation are load on the transformer, ambient temperature, wet content, and oxygen content in oil. Studies within the literature have used statistical approaches on check results for sensible insulation life assessment [1]. The degradation and reliableness of the paper oil- insulation system assessed by using accelerated life testing methods in [2]. Implementations in condition-monitoring techniques have helped transformer-life-management to assess the progressive deterioration of the insulation considering environmental factors [3]. Condition monitoring of liquid dielectrics is achieved by examining various critical parameters like BDV, acidity, viscosity, vol- 
ume resistivity, dielectric constant and loss tangent. The life decay on electrical performance of natural ester liquid due to thermal degradation discussed in [4]. The conferred approach to find the furan compounds in transformer oil was presented in [6]. In this work, same samples were exposed to different hours of thermal degradation under uniform electrical stress. Various specimen changes in the characteristic parameters of oil due to degradation were studied. In [7][8], an absolute Thermal Stress-UV analysis was conducted, in which decayed transformer oil were subjected to Ultra Violet Visible light and their spectral characteristics were evaluated. In the proposed work, comparatively less cost, samples of oil and paper used with an impact of thermal and electrical stress[9][10].

\section{Thermal Degradation Test}

\subsection{Test Cell}

The test cell was proposed to perform the setup of life study on transformer insulation system comprised of oil and conductor insulation, which operates at significantly above oil temperature. To achieve this goal, a model consisting of conductors hold up by insulation spacers with ground separation has been prepared. The complete sit-in was submerged in oil which is free to flow by natural convection. The exterior view of test cell is shown in Fig.1 and Fig. 2 shows the details of the conductor assembly. Table 1 shows the description of test box.

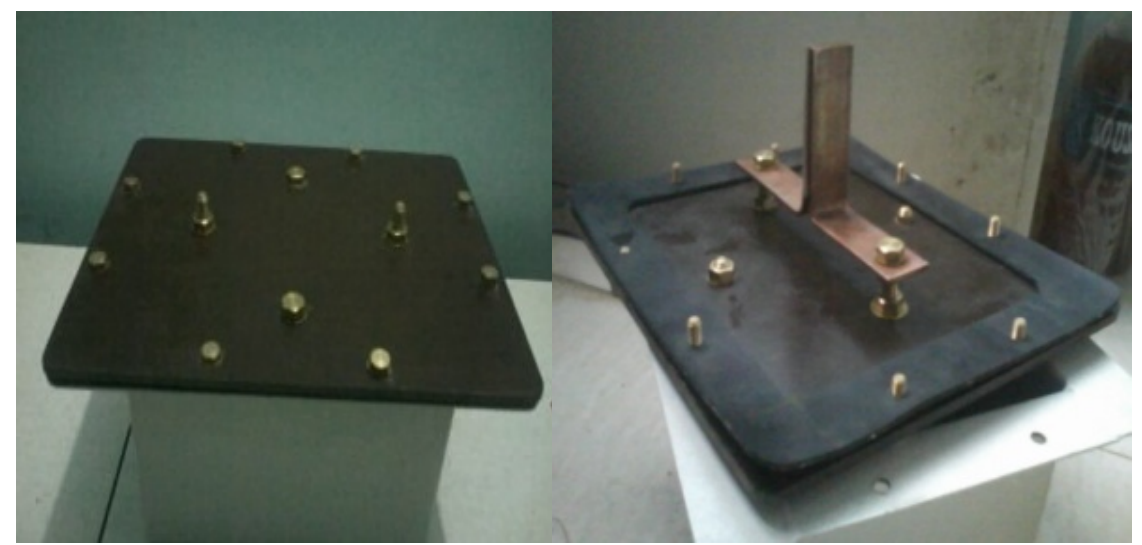

Fig. 1(a)

Fig. 1(b)

Fig. 1.(a) Overview of test cell(b).Conductor Assembly

Table 1. Specification of the Specimens

\begin{tabular}{lll}
\hline Category & Material & Dimension \\
\hline
\end{tabular}




\begin{tabular}{lll} 
cover plate & mica sheet & $8 \mathrm{~mm}$ \\
sealing ring & silicone rubber & $5 \mathrm{~mm}$ \\
tank & $\begin{array}{c}\text { M.S. (coated with enam- } \\
\text { el paint) }\end{array}$ & $200 \mathrm{~mm} \times 150 \mathrm{~mm} \times 150 \mathrm{~mm}$ \\
copper strip & copper & $130 \mathrm{~mm} \times 25 \mathrm{~mm} \times$ \\
& & $2.4 \mathrm{~mm}$ \\
insulation pa- & as per IS: 9335-1993 & $0.16 \mathrm{~mm}$ \\
per & & \\
bolt and nuts & brass & - \\
\hline
\end{tabular}

\subsection{Testing Procedure}

Inside the ventilation oven, the test cell was kept for accelerated electricalthermal stress studies on oil and paper. With the six layers of kraft paper, wound in half-laps on two sides of insulated conductors. Normal working stress on two electrodes is $1.0(\mathrm{kV})$. Dissimilar specimen of oil was used for ageing tests under electrical-thermal stress. The maximum temperature $120\left({ }^{\circ} \mathrm{C}\right)$ was maintained in the thermal ageing test and an air tight testing apparatus constructed with sealed environment. Several components of test performed in this effort are a) Transformer oil - Thermal degradation test b) Transformer oil with kraft paper and pressboard - Thermal degradation test. c) Transformer oil with kraft paper and pressboard Combined electrical thermal degradation test.

In this work, UV visible spectral performance of transformer oil with the joined thermal-electrical stress, the test is performed on pure transformer oil and also with the grouping of kraft paper and press board. The total weight $300 \mathrm{gm}$ of Press board and kraft paper with oil after long hours of heating in high voltage electrical stress. Transformer Oil (TO) dissimilar parts of test with their combination of materials is given in the Table 2. Under electrical stress with the heating of oil along with deterioration of solid insulation, the experiment was performed in real time. The level of degradation of transformer oil can indirectly determine based on the index results gathered from various specimens of transformer oil test. Apart from spectral response, it is necessary to obtain the critical parameters of transformer oil like BDV, dielectric constant, acidity and viscosity.

Table 2. Specification of the Specimens

\begin{tabular}{|c|c|c|}
\hline Module & $\begin{array}{l}\text { Specimen } \\
\text { name }\end{array}$ & Description \\
\hline \multirow{4}{*}{ Module I } & Specimen 1 & $20 \mathrm{~h}$ heated TO \\
\hline & Specimen2 & $40 \mathrm{~h}$ heated TO \\
\hline & Specimen3 & $80 \mathrm{~h}$ heated TO \\
\hline & Specimen4 & $100 \mathrm{~h}$ heated TO \\
\hline
\end{tabular}




\begin{tabular}{|c|c|c|}
\hline \multirow{5}{*}{ Module II } & Specimen5 & $120 \mathrm{~h}$ heated TO \\
\hline & Specimen6 & $20 \mathrm{~h}$ heated TO with pressboard and Kraft paper \\
\hline & Specimen 7 & $40 \mathrm{~h}$ heated TO with pressboard and Kraft paper \\
\hline & Specimen 8 & $80 \mathrm{~h}$ heated TO with pressboard and Kraft paper \\
\hline & Specimen 9 & $100 \mathrm{~h}$ heated TO with pressboard and Kraft paper \\
\hline \multirow{6}{*}{ Module III } & Specimen 10 & $120 \mathrm{~h}$ heated TO with pressboard and Kraft paper \\
\hline & Specimen 11 & $\begin{array}{l}20 \mathrm{~h} \text { heated TO with pressboard and Kraft paper under electri- } \\
\text { cal stress } 1 \mathrm{kV}\end{array}$ \\
\hline & Specimen 12 & $\begin{array}{l}40 \mathrm{~h} \text { heated TO with pressboard and Kraft paper under electrical } \\
\text { stress } 1 \mathrm{kV}\end{array}$ \\
\hline & Specimen 13 & $\begin{array}{l}80 \mathrm{~h} \text { heated TO with pressboard and Kraft paper under electrical } \\
\text { stress } 1 \mathrm{kV}\end{array}$ \\
\hline & Specimen 14 & $\begin{array}{l}100 \mathrm{~h} \text { heated TO with pressboard and Kraft paper under electri- } \\
\text { cal stress } 1 \mathrm{kV}\end{array}$ \\
\hline & Specimen 15 & $\begin{array}{l}120 \mathrm{~h} \text { heated TO with pressboard and Kraft paper under electri- } \\
\text { cal stress } 1 \mathrm{kV}\end{array}$ \\
\hline
\end{tabular}

\section{Results and Analysis}

\subsection{Transformer Oil - Thermal Degradation Test}

Test conducted with named as Module I, II and III, the corresponding results are given in Table 3.

Table 3Heating test on transformer oil

\begin{tabular}{|c|c|c|c|c|c|}
\hline $\begin{array}{l}\text { Specimen } \\
\text { No. }\end{array}$ & $\begin{array}{c}\text { No. of } \\
\text { Hours Heating }\end{array}$ & $\begin{array}{l}\text { Total acid } \\
\text { value } \\
(\mathrm{mg} \\
\mathrm{KOH} / \mathrm{g})\end{array}$ & $\begin{array}{l}\text { Vis- } \\
\text { cosity } \\
\text { (cSt) }\end{array}$ & $\begin{array}{c}\text { Break- } \\
\text { down voltage } \\
(\mathrm{kV} / 2.5 \\
\mathrm{mm})\end{array}$ & $\begin{array}{l}\text { Dielectric } \\
\text { constant }\end{array}$ \\
\hline 1 & 20 & 0.0323 & $\begin{array}{l}12.14 \\
02\end{array}$ & 38 & 1.52 \\
\hline 2 & 40 & 0.0643 & $\begin{array}{l}13.05 \\
43\end{array}$ & 36 & 1.36 \\
\hline 3 & 80 & 0.0812 & $\begin{array}{l}16.95 \\
87\end{array}$ & 35 & 0.83 \\
\hline 4 & 100 & 0.0923 & $\begin{array}{l}17.09 \\
32\end{array}$ & 33 & 0.54 \\
\hline 5 & 120 & 0.1264 & $\begin{array}{l}21.83 \\
78\end{array}$ & 30 & 0.52 \\
\hline 6 & 20 & 0.0924 & $\begin{array}{l}14.84 \\
35\end{array}$ & 34 & 0.83 \\
\hline 7 & 40 & 0.1855 & $\begin{array}{l}17.12 \\
34\end{array}$ & 31 & 0.64 \\
\hline
\end{tabular}




\begin{tabular}{llllll}
8 & 80 & 0.3134 & 18.43 & 32 & 0.32 \\
9 & 100 & 0.5545 & $\begin{array}{l}64 \\
45\end{array}$ & 29 & 0.15 \\
10 & 120 & 0.7073 & $\begin{array}{l}23.57 \\
78\end{array}$ & 26 & 0.12 \\
11 & 20 & 0.1024 & $\begin{array}{l}15.76 \\
23\end{array}$ & 34 & 0.51 \\
12 & 40 & 0.2089 & 14.35 & 39 & 0.25 \\
13 & 80 & 0.4553 & $\begin{array}{l}17.86 \\
53\end{array}$ & 29 & 0.11 \\
14 & 100 & 0.6264 & 21.74 & 27 & 0.08 \\
15 & 120 & 1.0552 & 26.78 & 25 & 0.05 \\
\hline
\end{tabular}

The variation of acidity with respect to hours of heating is shown in Fig.2. Heating of pure oil for long hours does not create much change in the acidity level. This is due to the lower quantity of moisture content and other impurities. For the second module, (Oil along with paper) the acidity value increases and the test process continued until the impurities in paper are absorbed. In the third module, with oil and paper under electrical stress, the acid level did not reach much of a level beyond 40 hours, which indicates that all the impurities responsible for oxidative process have been consumed, and hence no further oxidation and increase progressively of acidity upon further heating. However from the test results it is clearly shown that whenever oil is heated up to 120 hours, the level of acid content was increased up to 1 (mg $\mathrm{KOH} / \mathrm{g}$ ) (referred to accepted level). The variation of viscosity versus hours of heating is shown in Fig. 3.

The sound heat transfer capability and low-slung value of viscosity are required to accomplish high performance. To overcome narrow hotness, low-slug viscosity stimulates oil into initial penetration circulation through the windings and supports circulation through the windings, which would effect from further long-lasting dwelling of the oil at any hot spots. Viscosity of oil Equally important is the fact that viscosity of oil should increase as small as possible with loss in temperatures. With the heating of pure oil, viscosity value increases slowly until after 40 hours it does so steadily. The viscosity value increases rapidly in the oil and paper mixture at the start after 20 hours when the heating saturation occurs. Accelerated aging life, in the exclusive oil thermal degradation with electrical stress test, first 40 hours and the last 20 hours of heating of oil there is an increase of viscosity, saturated value of the viscosity in the middle. 


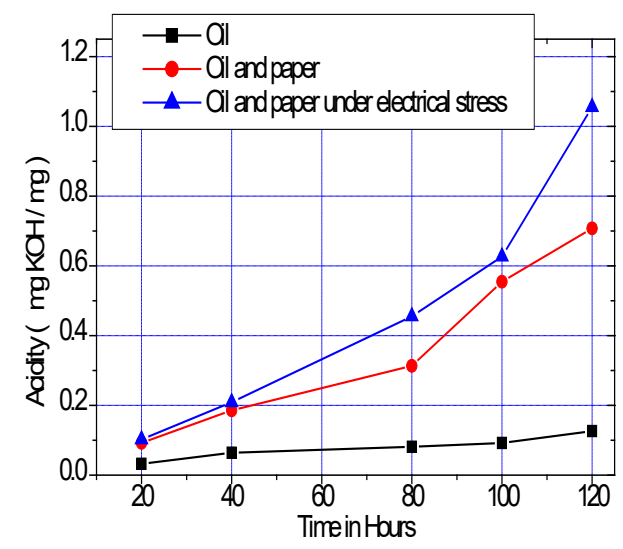

Fig. 2 Variation of Acidic value with time

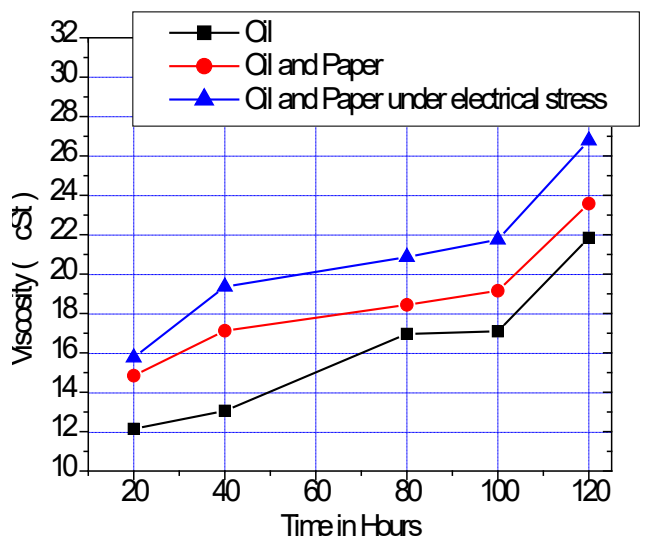

Fig.3 Variation of viscosity with time

The Fig.4 shows the results of accelerated aged specimens with breakdown voltage. With the rise in thermal and electric stress, the BDV of oil decreases uniformly. BDV decreases with the increase in moisture content in oil. It indicates that, BDV decreases with the increase in moisture content under electric and thermal stress. The water content and higher conducting impurities owing to oxidation of oil, result in BDV of the oil within transformer goes down slowly. Finally BDV reduction occurs because of the solid impurities released from the transformer. Fig.5 shows the results for the dielectric constants. With the oil and oil along with paper under usual electric stress, [9] the small change occurs in dielectric constant. However the oil and paper under accelerated electric stress shows the more dramatic variation in dielectric constant. 


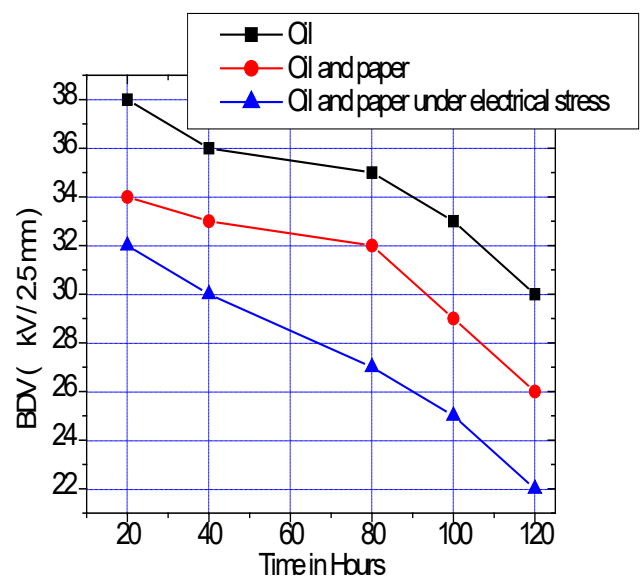

Fig.4 Variation of Break down voltage with time,

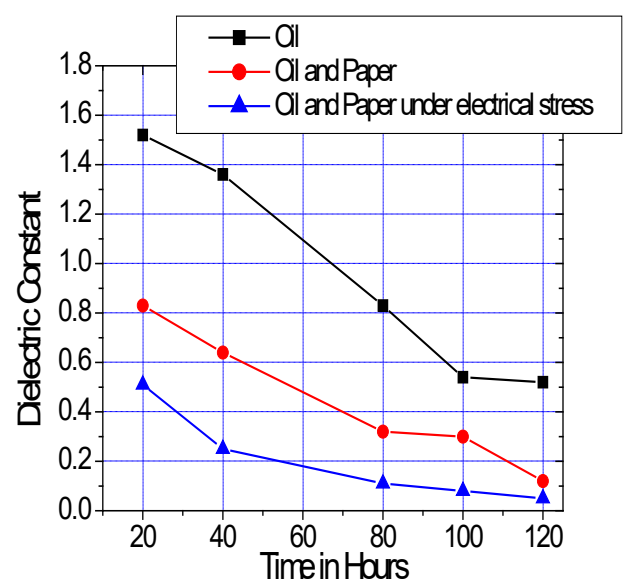

Fig.5 Variation of dielectric constant with time

\section{2 . UV response test on Transformer oil under the impact of Thermal-Electrical}

\section{Stress}

To analyze impurities in transformer oil by using light absorbing properties of the specimen, the UV-spectrometry is an perfect and accurate method. The light diffused over an oil specimen comprising is decreased by that segment being absorbed, which can be performed and calculated as a function of wavelength. A spectrometer assess the absorption or reflection, transmission of the light range for the given wavelength. Spectrometer provides realistic vales on the strength of the power transformer to estimate the value of effective life, relocation, maintenance, and operational criteria. The Spectrometry assess the overall condition of the transformer with accurate and 
the correlation between the UV trend and transformer aging can be easily recognized. The operation of spectrometry, the light enters through oil specimen containing various impurities and is decayed by that fraction being detected. In this work an experiment is performed with spectrometer having double beam facility. Fig. 6 shows the experiment was performed on an ELCO make SL 164 double beam Spectrometer.

To find the dissolve decay content distraction of various specimen of transformer oil using the experiment was performed on an ELCO make SL 164 double beam Spectrometer. Initially, using petroleum spirits or transformer oil clean the cuvettes. This experiment is carried out at room temperature in the range $20\left({ }^{\circ} \mathrm{C}\right)$ to $30\left({ }^{\circ} \mathrm{C}\right)$. During this process the reference sample is heptane (petroleum product) and it is filled in a glass cuvette and is placed in the reference sample holder, in UV Spectrometer as shown in Fig.7.

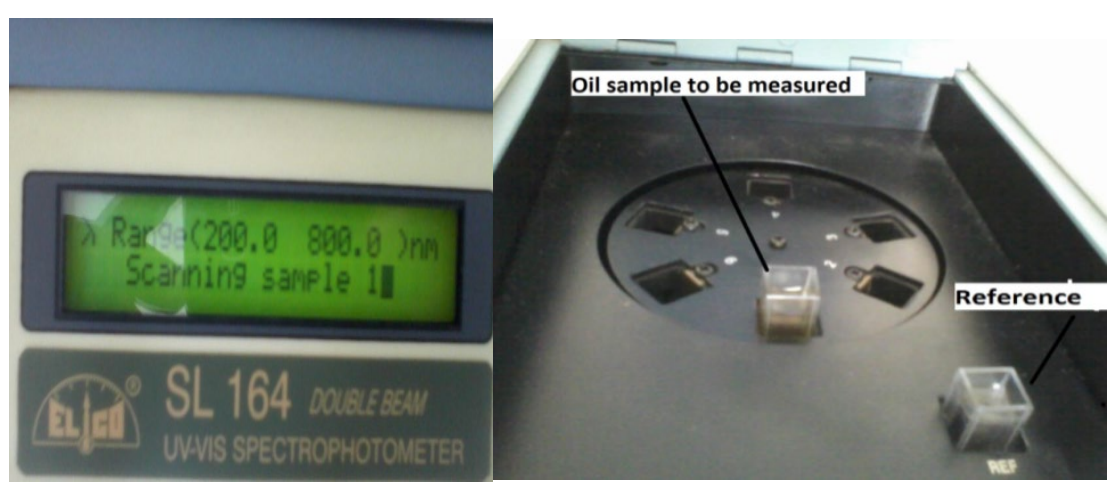

Fig.6 Double beam UV-VIS Spectrophotometer, Fig.7UV-VIS Spectrophotometer instrument samples holding unit

. The various hours of heating of pure transformer oil, a combination of oil-paper with thermal stress and combination of oil-paper with thermal-electrical stress test was performed. This is the indirect testing method of measuring the level of thermal degradation of oil. In table 4, the wave length of oil lies in the UV section, 200-500 (nm) and experiment outputs are presented. The peak absorption and wavelength graph obtained through spectra uses. Spectratreats software which was installed in the PC.Spectratreats software is used to communicate the spectral information to the external interface and facilitate the results in graphical form. The absorbance curve is attained from the device which scans in the range of 200-800 (nm). The total amount of dissolved decay products in mineral insulating oil shows that the relationship is exists between the absorbance curve.

Table 4. UV - Vis Spectral response of transformer oil

\begin{tabular}{lccc}
\hline Sample & No. of Hours & \multicolumn{2}{c}{ UV-Vis Response } \\
\cline { 3 - 4 } No. & Heating & ABS & Wave Length (nm) \\
\hline
\end{tabular}




\begin{tabular}{cccc}
1 & 20 & 0.105 & 230 \\
2 & 40 & 0.115 & 238 \\
3 & 80 & 0.123 & 244 \\
4 & 100 & 0.138 & 251 \\
5 & 120 & 0.142 & 264 \\
6 & 20 & 0.165 & 273 \\
7 & 40 & 0.258 & 284 \\
8 & 80 & 0.469 & 314 \\
9 & 100 & 0.897 & 328 \\
10 & 120 & 1.258 & 359 \\
11 & 20 & 1.46 & 372 \\
2 & 40 & 1.85 & 389 \\
13 & 80 & 2.064 & 397 \\
14 & 100 & 2.361 & 422 \\
15 & 120 & 2.643 & 430 \\
\hline
\end{tabular}

.If the oil is pure, the absorbance curves to the narrow wavelength. An increased content of dissolved decay products in the oil indicate that the curve between the absorbance and wavelengths shift to longer. The curve between absorbance and wavelengths is shorter then it indicates the selective removal of dissolved decay products in the transformer oil. Fig.8 shows the different spectral response of transformer oil for various modules. Clarification were made from the heating test conducted in oil with and without paper and the combination under thermal-electrical stress. From the first module bandwidth is low and absorbance is less, and thus the decay content is also less. In the second module, the oil-paper combination with or without electrical stress, the bandwidth is normal and absorbance is normal, therefore the decay content is also normal. In the third module, paper and oil under the impact of electrical stress, the bandwidth is high and absorbance is high then the decay content is also high and so on.

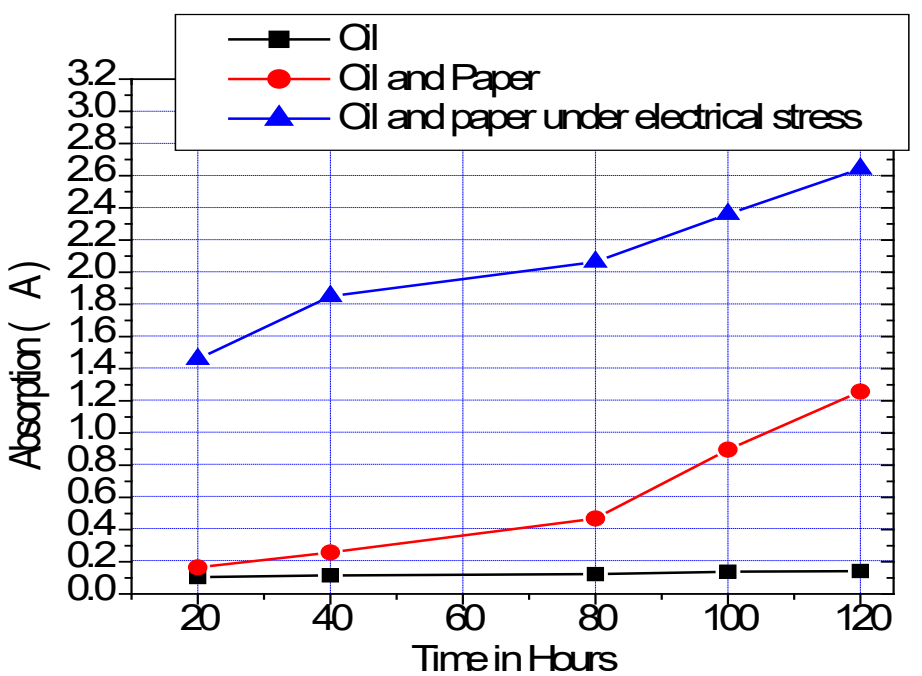


Fig.8 UV-Vis Spectral response of transformer oil under thermal electrical stress with heating hours

\section{Conclusion}

In this work, the accelerating age experiment is conducted with the different samples and the results are presented. This practice may verify to be substitute to oil conductivity experiment. It also indicates the dielectric characteristics and life assessment of transformer oil. The spectrometer test is used to detect the dissolved decay contents in oil for replacement of the transformer oil. Crucial parameters of oil are analyzed with combinations of insulation materials, for different level of electrical-thermal stress. The UV Spectral output of transformer oil can be calculated immediately by using relatively less cost equipment. Expert persons not required to perform the above test. Results demonstrate that there is a relationship between spectral response parameters with bandwidth and absorption and dissolved decay component in transformer oil

\section{References}

1. Muthanna, K. T., Sarkar, A., Das, K., and Waldner, K. Transformer insulation life assessment, ,IEEE Transactions on Power Delivery, 2005, Vol.21 (No.1), pp. 150-156.

2. Wang, Y., Gong, S., and Grzybowski, S. Reliability evaluation method for oil-paper insulation in power transformers. Energies, 2011,Vol.4 (No.9), pp. 1362-1375.

3. Srinivasan $M$ and Krishnan A, Effects of environmental factors in transformer's insulation life, WSEAS Transaction on Power System, 2013,Vol. 8, (No.35), pp.35-44..

4. Thakur, S., Panigrahi, S. K., Mishra, A. K., and Sarathi, R, Understanding the influence of ambience on thermal ageing of natural ester liquid, IET Science, Measurement \& Technology, 2018, Vol.13(No.2), pp.123-130.

5. Das, N., Abu-Siada, A., and Islam, S, New approach to estimate furan contents in transformer oil using spectroscopic analysis, (2012) $22^{\text {nd }}$ Australasian Universities Power Engineering Conference (AUPEC), pp.1-4..

6. Leong, Y. S., Ker, P. J., Jamaludin, M. Z., Saiffuddin, M., Nomanbhay, A., Ismail, F., Characterizing Inhibitor Content of Transformer Oil in the UV-Visible Wave band, (2018), IEEE $7^{\text {th }}$ International Conference on Photonics (ICP), pp. 1-3.

7. Radha, K., and Thangaswamy, S. R. R, Investigations of thermal degradation and spectral response of transformer oil, ActaScientiarum. Technology, (2013),Vol. 35, No. 2, pp.255262.

8. S. T. Ahmed, H. K. Priyanka, S. Attar and A. Patted, "Cataract density ratio analysis under color image processing approach," 2017 International Conference on Intelligent Computing and Control Systems (ICICCS), Madurai, 2017, pp. 178-180, doi: 10.1109/ICCONS.2017.8250705

9. Thouheed Ahmed S., Sandhya M. (2019) "Real-Time Biomedical Recursive Images Detection Algorithm for Indian Telemedicine Environment". In: Mallick P., Balas V., Bhoi A., Zobaa A. (eds) Cognitive Informatics and Soft Computing. Advances in Intelligent Systems and Computing, vol 768. Springer, Singapore. https://doi.org/10.1007/978981-13-0617-4_68 
10. Kumar, S.S., Ahmed, S.T., Vigneshwaran, P. et al. "Two phase cluster validation approach towards measuring cluster quality in unstructured and structured numerical datasets". J Ambient Intell Human Comput (2020). https://doi.org/10.1007/s12652-020-02487-w 